\title{
ANALISIS PERLAKUAN AKUNTANSI ASET TETAP PADA PT. MUARA DUA PALEMBANG BERDASARKAN SAK ETAP NO. 15 Rizal Effendi ${ }^{1}$, Kartawinata ${ }^{2}$
}

\author{
1, Dosen jurusan Akuntansi, Universitas Tridinanti, Sumatera Selatan \\ 2, Dosen jurusan Manajemen, Universitas Tridinanti, Sumatera Selatan \\ 1)Email : effendirizal37@gmail.com, ${ }^{2) E m a i l ~: ~ k a r t a w i n a t a 1959 @ g m a i l . c o m ~}$
}

\section{Submitted: \\ $10 / 11 / 2021$ \\ Revised: \\ $15 / 12 / 2021$ \\ Accepted: \\ $25 / 12 / 2021$ \\ Online-Published: \\ $31 / 12 / 2021$}

INFORMASI ARTIKEL

\begin{abstract}
ABSTRAK
Dalam menghadapi persaingan yang ketat dalam dunia bisnis, perusahaan harus berusaha untuk mempertahankan peningkatan keuntungan atau profit di dalam perusahaan. Peningkatan yang terjadi pada perusahaan dapat dilihat dari laporan keuangannya, karena laporan tersebut digunakan untuk mengevaluasi kondisi perusahaan dan untuk memperkirakan hasil usaha dan arus kas di masa yang akan datang.

Laporan keuangan merupakan media komunikasi dan informasi bagi pihak internal dan eksternal perusahaan. Salah satu bentuk laporan keuangan adalah laporan laba rugi dan neraca. Laporan laba rugi melaporkan pendapatan dan pengeluaran selama periode waktu tertentu sedangkan neraca melaporkan total aset, kewajiban, dan ekuitas pemilik pada tanggal tertentu. Laporan keuangan harus disajikan secara tepat dan akurat karena laporan keuangan akan digunakan sebagai salah satu bahan pertimbangan pengambilan keputusan di masa yang akan datang.
\end{abstract}

Kata kunci: Laporan keuangan, laporan laba rugi dan neraca

\begin{abstract}
ABSTRACK
In the face of fierce competition in the business world, companies must strive to maintain increased profits or profits within the company. The increase that occurred in the company can be seen from its financial statements, because these reports are used to evaluate the condition of the company and to estimate the results of operations and cash flows in the future.

Financial reports are a medium of communication and information for internal and external parties of the company. One form of financial statements is the income statement and balance sheet. The income statement reports income and expenses over a certain period of time whereas the balance sheet reports the total assets, liabilities and owner's equity as of a specific date. Financial statements must be presented appropriately and accurately because the financial statements will be used as one of the considerations for decision making in the future.
\end{abstract}

\section{A. PENDAHULUAN}

Menghadapi dunia usaha yang ketat akan persaingan, perusahaan harus berusaha untuk mempertahankan peningkatan keuntungan atau laba dalam perusahaan. Peningkatan yang terjadi pada perusahaan dapat dilihat dari laporan keuangannya, karena laporan tersebut digunakan untuk mengevaluasi kondisi perusahaan dan untuk memperkirakan hasil operasi serta arus kas di masa depan.
Laporan keuangan merupakan salah satu media komunikasi dan informasi bagi pihak internal maupun eksternal perusahaan. Salah satu bentuk laporan keuangan adalah laporan laba rugi dan neraca. Laporan laba rugi melaporkan pendapatan dan beban selama periode waktu tertentu sedangkan neraca melaporkan jumlah aset, kewajiban dan ekuitas pemilik pada tanggal tertentu. Laporan keuangan harus disajikan secara tepat dan akurat karena laporan keuangan akan digunakan 
sebagai salah satu bahan pertimbangan untuk pengambilan keputusan di masa yang akan datang.

Penetapan tujuan perusahaan akan membantu perusahaan dalam mengambil suatu keputusan. Tujuan suatu perusahaan adalah untuk memperoleh laba yang optimal atas investasi yang ditanamkan pada perusahaan. Salah satu bentuk investasi yang ada dalam perusahaan adalah aset tetap yang memiliki umur ekonomis di atas satu tahun. Untuk mencapainya diperlukan pengelolaan yang efektif dalam penggunaan, pemeliharaan maupun pencatatan akuntansinya.

Menurut Suharli (2016: 259) menyatakan aset tetap adalah harta berwujud (tangible asset) yang memiliki masa manfaat ekonomis lebih dari satu tahun bernilai material, dan digunakan untuk kegiatan operasi normal perusahaan dan merupakan pengeluaran yang nilainya besar atau material.

Aset tetap pada dasarnya bisa memberikan gambaran kapitalisasi yang wajar, oleh karena itu dibutuhkan adanya perlakuan akuntansi yang memadai mulai dari saat perolehan sampai dengan saat pengalokasian biaya selama umur aset tetap tersebut. Perlakuan aset tetap ini bertujuan untuk memberikan kelayakan penyajian aset tetap sebagai salah satu bagian dari harta kekayaan perusahaan secara keseluruhan.

Aset tetap juga berkontribusi terhadap kelayakan laporan keuangan. Kesalahan dalam menilai aset tetap dapat menyebabkan kesalahan yang cukup material karena nilai investasi yang ditanamkan pada aset tetap relatif besar. Oleh karena itu, untuk memperoleh laporan keuangan yang wajar, mengakibatkan munculnya kebutuhan akan standar akuntansi yang berlaku secara nasional. IAPI atau Ikatan Akuntan Publik Indonesia menerbitkan standar akuntansi untuk Usaha Kecil Menengah yaitu SAK ETAP (Standar
Akuntansi Keuangan Entitas Tanpa Akuntabilitas Publik). Salah satu Standar Akuntansi Keuangan tersebut harus digunakan perusahaan yang masih tergolong Usaha Kecil Menengah (UKM) dalam menyusun laporan keuangan khususnya pengelolaan aset tetap yang tercantum dalam Standar Akuntansi Keuangan Entitas Tanpa Akuntabilitas Publik (SAK ETAP) No.15 atas Aset Tetap.

Standar Akuntansi Keuangan Entitas Tanpa Akuntabilitas Publik (SAK ETAP) pertama kali diterbitkan pada 17 Juli 2009 berlaku efektif 1 Januari 2011. Penerapan Standar Akuntansi Keuangan Entitas Tanpa Akuntabilitas Publik adalah untuk entitas yang tidak memiliki akuntabilitas public signifikan dan menerbitkan laporan keuangan untuk tujuan umum (general purpose financial statement) bagi pengguna eksternal (pemilik yang tidak terlibat langsung dalam pengelolaan usaha).

Perusahaan perlu memperlakukan akuntansi aset tetap tersebut sesuai dengan Standar Akuntansi Keuangan Entitas Tanpa Akuntabilitas Publik. Aset tetap pada setiap perusahaan akan memiliki jenis yang berbeda satu sama lainnya. Bahkan perusahaan yang bergerak di bidang usaha yang sama, belum tentu memiliki aset tetap yang sama. Dalam menjalankan penggunaan atas aset tetap tersebut akan ada beban yang dikeluarkan setiap tahun selama masa manfaatnya yaitu beban penyusutan aset tetap. Beban penyusutan merupakan beban pengalokasian biaya perolehan aset tetap dalam periode akuntansi. Beban ini muncul karena secara berkala aset tetap akan mengalami penurunan manfaat sehingga menurunkan nilai ekonomis aset tersebut.

PT. Muara Dua merupakan salah satu perusahaan yang bergerak di bidang usaha perdagangan. Aset tetap yang dimiliki PT. Muara Dua berupa bangunan, inventaris kantor dan 
kendaraan. Perlakuan akuntansi yang dilakukan oleh PT. Muara Dua meliputi segala tindakan yang berhubungan dengan aset tetap tersebut yaitu saat menentukan harga perolehan dan pencatatan aset tetap serta penyajiannya dalam laporan keuangan. PT. Muara Dua dalam menentukan harga perolehan didapat dengan cara harga belinya saja. Kesalahan dalam menerapkan perlakuan akuntansi atas aset tetap akan mempengaruhi laporan keuangan, khususnya dalam laporan laba-rugi dan neraca.

Berdasarkan hasil dari wawancara dengan kepala bagian akuntansi, PT Muara Dua menggunakan metode garis lurus dalam perhitungan penyusutan aset tetapnya. Risiko yang dihadapi oleh pengguna metode garis lurus ini adalah kesalahan perhitungan pada tahun pertama akan berakibat terus menerus selama umur manfaat aset tetap tersebut berakhir.

Permasalahan yang terjadi di dalam perusahaan adalah menyangkut aset tetap berwujudnya, yaitu perusahaan mengakui harga perolehan aset tetap sebesar harga pembelian. Selain itu, dalam pencatatan aset tetap perusahaan sudah melakukan penyusutan dengan menggunakan metode garis lurus tetapi nilai beban penyusutannya tidak menunjukkan nilai yang selayaknya. Hal ini dikarenakan pada saat proses perhitungan penyusutan, perusahaan menghitung penyusutan awal. Pada tahun selanjutnya, perusahaan tidak memperhitungkan kembali nilai penyusutan tersebut.

Berdasarkan pengamatan yang dilakukan peneliti, maka permasalahan yang terdapat di dalam penelitian ini adalah Bagaimana perlakuan akuntansi aset tetap pada PT.Muara Dua Palembang Berdasarkan SAK ETAP No. 15?

Adapun tujuan dari penelitian ini adalah untuk mengetahui perlakuan akuntansi aset tetap pada PT Muara Dua
Palembang Berdasarkan SAK ETAP No. 15.

\section{B. METODE PENELITIAN \\ 1. Rancangan Penelitian}

Rancangan penelitian adalah rekayasa operasional bagaiman sebuah penelitian akan dilaksanakan dalam rangka meminimalkan unsur kekeliruan (eror). Dengan kata lain rancangan penelitian merupakan pedoman yang berisi langkah - langkah yang akan diikuti oleh peneliti dalam melakukan penelitian.

Metode penelitian ini merupakan penelitian deskriptif kualitatif, dimana penelitian bertujuan untuk mendeskriptifkan prosedur penerimaan dan pengeluaran kas PT.Muara Dua Palembang.

\section{Variabel dan Defenisi Operasional}

Menurut Syofian Siregar (2018:109), Variabel adalah konsep yang mempunyai bermacam-macam nilai merupakan kuantitatif maupun kualitatif yang dapat berubah-ubah nilainya.

Menurut Syofian Siregar (2018:121), Definisi Operasional adalah suatu definisi yang didasarkan pada karakteristik yang dapat diobservasi dari apa yang sedang didefinisikan.

Variabel penelitian ini adalah sistem infiormasi akuntansi penjualan dan sistem informasi akuntansi penerimaan kas, agar tidak terjadi kekeliruan dalam penafsirkan mengenai variabel penelititan maka perlu adanya defenisi operasional yang menjadi batasannya.

\section{Prosedur Pengumpulan Data}

a. Observasi

Yaitu dengan melakukan pengamatan secara langsung terhadap objek penelitian.

b. Interview 
Yaitu dilakukan dengan cara wawancara kepada pihak yang berhubungan dengan permasalahan penelitian.

\section{Teknik Analisis}

Menurut Sugiyono (2016:81), Teknik analisis dapat dibedakan menjadi 2 (dua) macam yaitu :

1. Teknik Analisis Data Kualitatif

Merupakan data yang tidak berbentuk angka. Misalnya preferensi konsumen, kepuasan konsumen, rumah tangga miskin, kestabilan harga, motivasi dan lain - lain. Sebelum dianalisis, data kualitatif ini harus diskalakan dulu misalnya dalam skala nominal dan ordinal.

2. Teknik Analisis Data Kuantitatif

Merupakan data berupa angka hasil pengukuran atau penghitungan (counting), misalnya produksi padi (ton), gaji karyawan (Rp), harga komputer (Rp), atau jumlah karyawan (orang). Data kuantitatif ini dapat diklasifikasikan juga dalam data disktrit (Hasil hitungan) dan data kontinyu (hasil Pengukuran).

Penelitian ini menggunakan teknik analisis data kualitatif. Dimana pada teknik ini dapat digambarkan proses penelitian itu mulai dari pencatatan, pengklasifikasian, penguraian serta proses pengumpulan data sehingga dapat mengetahui penyelesaian mengenai permasalahan sistem infiormasi akuntansi penjualan dan sistem informasi akuntansi penerimaan kas pada objek penelitian sesuai dengan teori yang sudah ada.

\section{HASIL DAN PEMBAHASAN}

Hasil penelitian yang dilakukan peneliti menunjukkan bahwa perusahaan PT. Muara Dua Palembang dalam melaksanakan perlakuan aset tetap berdasarkan SAK ETAP adalah sebagai berikut :

\section{Perlakuan Akuntansi Aset Tetap Pada PT. Muara Dua Palembang}

Berdasarkan SAK ETAP pada

bab 15 mengenai aset tetap, perlakuan akuntansi PT. Muara Dua Palembang yang mana penilaiannya menggunakan metode biaya telah sesuai dengan peraturan seperti yang dinyatakan dalam paragraf 15.10 yang menyebutkan bahwa pada saat pengakuan awal, aset tetap harus diukur sebesar biaya perolehan. Adapun biaya perolehan aset tetap adalah setara harga tunainya pada tanggal pengakuan. nilai dari aset tetap yang dinyatakan dan dicatat PT. Muara Dua Palembang berdasarkan biaya perolehan sesuai dengan peraturan yang ditetapkan oleh SAK ETAP.

PT. Muara Dua Palembang mencatat aset tetap sebesar biaya perolehan. Harga beli dan biaya-biaya yang dikeluarkan sampai aset tersebut siap digunakan telah dikapitalisasi ke biaya perolehan. Penilaian kembali atau revaluasi aset tetap pada umumnya tidak diperkenankan karena SAK ETAP menganut penilaian aset berdasarkan biaya perolehan atau harga pertukaran.

\section{Pengukuran Aset Tetap}

Penyusutan menggunakan metode garis lurus diperbolehkan dalam SAK ETAP yang tertuang dalam paragraf 15.22 yang mana disebutkan bahwa beberapa metode penyusutan yang mungkin dipilih yaitu metode garis lurus, metode saldo menurun, dan metode jumlah unit produksi. Atas kebijakan penyusutan yang ditetapkan perusahaan dengan menggunakan metode garis lurus tersebut, PT. Muara Dua Palembang telah melakukannya secara konsisten sejak 
awal akuisisi aset yang dimiliki oleh PT. Muara Dua Palembang.

Jika melihat informasi yang disajikan pada tabel Penghitungan Penyusutan Aset Tetap, terdapat perbedaan antara penghitungan basis bulan yang dilakukan oleh PT. Muara Dua Palembang dengan rekalkulasi yang dilakukan berdasarkan hari. Perbedaan ini mengakibatkan penghitungan akumulasi depresiasi yang dihitung oleh PT. Muara Dua Palembang lebih kecil dibandingankan dengan rekalkukasi akumulasi depresiasi yang dilakukan berdasarkan hari yang berarti ada undercalculated atas penghitungan yang dilakukan oleh PT PRS. Undercalculated atas penghitungan terhadap akun akumulasi depresiasi akan mengakibatkan nilai aset tetap lebih besar dari yang seharusnya sehingga bisa mengakibatkan adanya overstatement yang merupakan kecenderungan kesalahan penyajian suatu akun pada pos aset. Namun atas perbedaan ini tidak lakukan penyesuaian karena nilai perbedaan yang ada berada di bawah nilai materialitas yang ditetapkan oleh suatu Kantor Akuntan Publik.

Perbedaan yang ditemukan atas penghitungan akumulasi penyusutan menggunakan basis bulan yang dilakukan antara PT. Muara Dua Palembang dengan penghitungan depresiasi basis hari melalui bantuan rumus =ROUND (number, num_digits) pada software Microsoft Excel sehingga pada akhirnya penghitungan basis hari pasti akan lebih besar jika dibandingkan dengan penghitungan yang dilakukan oleh PT. Muara Dua Palembang. Perbedaan penghitungan aset tetap yang lebih besar dengan basis hari dibandingkan dengan penghitungan PT. Muara Dua Palembang melalui penghitungan basis bulan merupakan hal yang biasa terjadi, jika perbedaan yang ada tidak melebihi batas PM (Performance Materiality) untuk akun aset (80\% dari Overall Materiality) dan saat masuk SUD (Summary of Unadjusted Different) tidak melebihi batas yang ditetapkan KAP yaitu sebesar 3\% dari OM (Overall Materiality) maka tidak perlu dilakukan penyesuaian atas akun yang bersangkutan.

\section{Penghentian Aset Tetap}

Penghapusan aset tetap pada PT. Muara Dua Palembang dengan cara mendebit akumulasi penyusutan dan mengkredit biaya perolehan aset tetap yang bersangkutan. Cara yang digunakan untuk melepaskan aset tetap adalah dengan memperhitungkan nilai buku yaitu harga perolehan dikurangi akumulasi penyusutan, dengan perhitungan ini, maka harga perolehan yang semula didebet harus dikreditkan. Akumulasi Penyusutan yang semula.kredit harus didebetkan. Sedangkan nilai buku harus didebet dan dianggap sebagai kerugian pelepasan. Dengan penjurnalan di atas, secara otomatis aset tetap akan terhapus dari buku perusahaan.

Masih tercatatnya aset tetap dalam laporan pada PT. Muara Dua Palembang dimungkinkan untuk dilakukan karena suatu aset yang sudah didepresiasi secara penuh tidak perlu dikeluarkan dari pencatatan jika masih digunakan dalam bisnis suatu entitas. Tidak dikeluarkannya aset tersebut dalam pencatatan akan menjadi bukti keberadaan aset tersebut. perusahaan baru melakukan write off atau penghentian pengakuan atas aset tetap tersebut karena aset tersebut tidak lagi digunakan serta dianggap tidak lagi memiliki manfaat ekonomi dimasa depan yang dapat diekspektasikan dari penggunaannya sesuai yang diatur dalam paragraf 15.28 SAK ETAP. Kebenaran pelepasan ini diuji dengan 2 (dua) cara yaitu:

1. Melakukan pemeriksaan apakah aset yang dilepaskan memang benar sudah dikeluarkan dari pencatatan dan melakukan uji 
akurasi penghitungan daftar aset tetap.

2. Menguji kebenaran adanya penurunan aset tetap dengan membandingkan nilai aset tetap pada tahun sebelumnya.

Dalam hal ini, PT. Muara Dua Palembang belum melaksanakan penghentian pengakuan sesuai dengan standar yang diatur oleh SAK ETAP karena tidak didukung laporan daftar pelepasan aset yang dilakukan PT. Muara Dua Palembang. Hal ini menyebabkan penghitungan daftar aset tetap menjadi tidak akurat karena tidak ada informasi aset yang dilepaskan memang benar sudah dikeluarkan atau belum.

\section{Pengungkapan dan Pelaporan Aset Tetap}

PT. Muara Dua Palembang sudah menyajikan aset tetap sesuai dengan SAK ETAP karena sudah dikelompokkan sebagai aset tetap berwujud dan jangka waktu penggunaanya lebih dari satu periode akuntansi serta digunakan untuk kegiatan operasi perusahaan. Namun untuk Catatan atas Laporan Keuangan pada aset tetap perusahaan belum dibuat dan dicantumkan PT. Muara Dua Palembang dalam laporan keuangan.

Berdasarkan SAK ETAP No 15.14 menyatakan bahwa:

"Entitas harus mengukur seluruh aset tetap setelah pengakuan awal pada biaya perolehan dikurangi akumulasi penyusutan dan akumulasi kerugian penurunan nilai. Entitas harus mengakui biaya pemeliharaan dan reparasi seharisehari (cost of day-to-day servicing) dari aset tetap sebagai beban dalam laporan laba rugi pada periode terjadinya"

\section{SIMPULAN DAN SARAN}

\section{Simpulan}

Secara keseluruhan perlakuan aset tetap yang dilaksanakan oleh PT. Muara Dua Palembang masih belum sesuai dengan SAK ETAP No. 15, dan masih terdapat perlakuan akuntansi aset yang kurang sesuai dengan SAK ETAP. Berdasarkan penelitian dan pembahasan yang Penulis kemukakan terhadap perlakuan akuntansi aset tetap yang dilakukan oleh PT. Muara Dua Palembang, maka dapat diambil kesimpulan sebagai berikut:

1. Pengakuan nilai dari aset tetap yang dinyatakan dan dicatat PT. Muara Dua Palembang berdasarkan biaya perolehan sudah sesuai dengan peraturan yang ditetapkan oleh SAK ETAP No. 15.

2. Pengukuran aset tetap dengan metode garis lurus pada PT. Muara Dua Palembang masih menggunakan basis bulan yang memiliki perbedaan penghitungan aset tetap dengan metode garis lurus basis harian. Perbedaan penghitungan terhadap akun akumulasi depresiasi akan mengakibatkan adanya overstatement yang merupakan kecenderungan kesalahan penyajian suatu akun pada pos aset.

3. Penghentian pengakuan pada PT. Muara Dua Palembang masih belum sesuai dengan standar yang diatur oleh SAK ETAP No. 15 karena tidak didukung laporan daftar pelepasan aset.

4. Pengungkapan dan penyajian laporan keuangan pada PT. Muara Dua Palembang masih belum sesuai dengan SAK ETAP No. 15 karena laporan keuangan belum disertai dengan Catatan Atas Laporan Keuangan untuk aset tetap yang disajikan.

\section{Saran}

Berdasarkan hasil analisis dalam penelitian ini, maka ada beberapa saran yang diberikan oleh penulis yaitu: 
1. Pihak perusahaan harus tetap mempertahankan pengakuan biaya aset tetap berdasarkan biaya perolehan karena hal ini sudah sesuai dengan yang ditetapkan SAK ETAP No. 15.

2. Pihak perusahaan dalam melakukan pengukuran aset tetap harus melakukan perubahan dengan metode garis lurus yang menggunakan basis harian agar tidak terjadi kesalahan penghitungan akumulasi penyusutan aset tetap.

3. Pihak perusahaan dalam melakukan penghentian aset tetap harus membuat laporan daftar inventaris yang terbaru, yang sesuai dengan aset tetap yang ada. Jika aset tetap tersebut telah mengalami kerusakan, sebaiknya dilakukan penghapusan dan tidak perlu disajikan pada laporan serta perlu dibuat juga daftar pelepasan aset tetap tersebut.

4. Pihak perusahaan dalam pengungkapan dan penyajian aset tetap perlu membuat dan melengkapi laporan keuangan dengan Catatan Atas Laporan Keeuangan (CALK).

\section{E. DAFTAR RUJUKAN}

Arikunto, Suharsimi. 2018. Manajemen Penelitian. Edisi Revisi. Jakarta: Rineka Cipta.

Firdaus. 2008. Pengantar Akuntansi. Edisi Keempat, Jakarta: Lembaga Penerbit FE UI.

Dewan Standar Akuntansi Keuangan. 2018. Standar Akuntansi Keuangan Entitas Tanpa Akuntabilitas Publik. Jakarta: Ikatan Akuntan Indonesia.
Ikatan Akuntan Indonesia (IAI). 2014. Standar Akuntansi Keuangan. Jakarta: Ikatan Akuntan Indonesia.

Reeve, James.R, et.al. 2018. Pengantar Akuntansi Adaptasi Indonesia. Buku 2. Jakarta: Salemba Empat.

Rudianto. 2018. Pengantar Akuntansi. Jakarta: Erlangga.

Sugiri, Slamet. 2017. Akuntansi Suatu Pengantar. Edisi Kelima. Yogjakarta: UPP STIM YKPN.

Sugiyono. 2018. Metode Penelitian Kuantitatif, Kualitatif dan Kombinasi (Mixed Methods). Bandung: Alfabeta.

Suharli, Michell. 2016. Akuntansi Untuk Bisnis Jasa dan Dagang. Edisi Pertama. Yogyakarta: Penerbit Graha Ilmu.

Suradi, R dan Hegar. 2016. Laporan Keuangan. Jakarta: IDAI. 